\title{
KOMORBIDITAS GANGGUAN TIDUR PADA ANAK DENGAN GANGGUAN PEMUSATAN PERHATIAN DAN HIPERAKTIVTAS (GPPH)
}

\author{
Evi $^{1}$, Tjhin Wiguna ${ }^{2}$, Khamelia Malik ${ }^{3}$ \\ ${ }^{1}$ Jurusan Fakultas Kedokteran, Universitas Tarumanagara Jakarta \\ Email: evi.fkuntar@gmail.com \\ ${ }^{2}$ Departemen Psikiatri, Universitas Indonesia Jakarta \\ Email:twiga00@yahoo.com \\ ${ }^{3}$ Departemen Psikiatri, Universitas Indonesia Jakarta \\ Email:khameliapsi@gmail.com
}

Masuk : 10-03-2021, revisi: 28-04-2021, diterima untuk diterbitkan : 29-05-2021

\begin{abstract}
ABSTRAK
Gangguan Pemusatan Perhatian dan Hiperaktivitas (GPPH) adalah gangguan perkembangan yang ditandai dengan kesulitan dalam mempertahankan atensi, disorganisasi dan atau perilaku psikomotor yang hiperaktif. Patofisiologi dan etiologi GPPH sangat kompleks, bersifat multiaksial dan multifaktorial, melibatkan faktor genetik, lingkungan, berbagai perubahan pada struktur, fungsi dan biokimia dari otak. Sebagai konsekuensinya, GPPH umumnya tidak berdiri sendiri melainkan sering disertai oleh satu atau lebih kondisi komorbid di mana salah satu di antaranya adalah gangguan tidur. Gangguan tidur memang dapat terjadi pada setiap orang, akan tetapi prevalensi gangguan tidur pada GPPH kira-kira 5 kali lebih banyak dari pada tanpa GPPH. Hubungan antara gangguan tidur dan GPPH bersifat kompleks dan multidireksional. Gangguan tidur dapat merupakan gejala dari GPPH, dapat diperburuk oleh GPPH, atau sebaliknya membuat gejala seperti GPPH, dan menambah gejala GPPH bertambah berat.
\end{abstract}

Kata kunci : Gangguan Pemusatan Perhatian dan Hiperaktivitas (GPPH); gangguan tidur; Sleep Disorder Breathing (SDB); Restless Leg Syndrome (RLS); Periodic Limb Movement Disorder (PLMD)

\section{ABSTRACT}

Gangguan Pemusatan Perhatian dan Hiperaktivitas (GPPH) adalah gangguan perkembangan yang ditandai dengan kesulitan dalam mempertahankan atensi, disorganisasi dan atau perilaku psikomotor yang hiperaktif. Patofisiologi dan etiologi GPPH sangat kompleks, bersifat multiaksial dan multifaktorial, melibatkan faktor genetik, lingkungan, berbagai perubahan pada struktur, fungsi dan biokimia dari otak. Sebagai konsekuensinya, GPPH umumnya tidak berdiri sendiri melainkan sering disertai oleh satu atau lebih kondisi komorbid di mana salah satu di antaranya adalah gangguan tidur. Gangguan tidur memang dapat terjadi pada setiap orang, akan tetapi prevalensi gangguan tidur pada GPPH kira-kira 5 kali lebih banyak dari pada tanpa GPPH. Hubungan antara gangguan tidur dan GPPH bersifat kompleks dan multidireksional. Gangguan tidur dapat merupakan gejala dari GPPH, dapat diperburuk oleh GPPH, atau sebaliknya membuat gejala seperti GPPH, dan menambah gejala GPPH bertambah berat.

Keywords : Attention Deficit and Hyperactivity Disorder (ADHD); sleep problem; Sleep Disorder Breathing (SDB); Restless Leg Syndrome (RLS); Periodic Limb Movement Disorder (PLMD)

\section{PENDAHULUAN}

Gangguan Pemusatan Perhatian dan Hiperaktivitas (GPPH) adalah gangguan psikiatri yang umum pada anak-anak, ditandai dengan ketidakmampuan mempertahankan atensi yang tidak sesuai dengan level tumbuh kembangnya, kegelisahan dan atau perilaku psikomotor yang hiperaktif dan impulsif, yang sering kali menyebabkan hendaya dalam fungsi akademik, sosial dan dalam hubungan interpersonal. ${ }^{1}$

GPPH umumnya disertai dengan berbagai kondisi komorbid seperti : gangguan belajar (15$25 \%$ ), gangguan berbahasa (30-35\%), gangguan fungsi sosial adaptasi seperti autis (10\%), emosional yang labil (15-20\% berupa gangguan mood dan 20-25\% berupa gangguan kecemasan), defisit koordinasi motorik dan defisit keseimbangan (60\%), obesitas, gangguan 
tidur, yang di kemudian hari dapat diikuti dengan risiko potensial berupa gangguan pemberontak oposisi $(40 \%)$, gangguan perilaku $(20 \%)$, penyalahgunaan zat $(15 \%)$ dan perilaku kriminal. Menurut studi, 59-87\% GPPH disertai dengan 1 kondisi komorbid, 20\% disertai sampai 3 atau lebih kondisi komorbid. ${ }^{2,3}$

Menurut literatur, 25-50\% orang tua melaporkan anak dengan GPPH memiliki gangguan tidur. Dan menurut perhitungan, prevalensi gangguan tidur pada GPPH ini kira-kira 5 kali lebih banyak dari pada tanpa GPPH. ${ }^{4,5}$ Dalam DSM - III gangguan tidur sempat menjadi salah satu kriteria diagnosis GPPH, meskipun kriteria ini akhirnya dieliminasi pada edisi DSM berikutnya. GPPH dan gangguan tidur memiliki hubungan yang erat, kompleks, bersifat multidireksional dan multifaktorial. Multidireksional artinya pada satu sisi, gejala GPPH mengganggu tidur dengan meningkatnya kesulitan menyuruh mereka tidur, durasi tidur yang pendek, higiene tidur yang kurang, dan kualitas tidur yang buruk. Sebaliknya, gangguan tidur seperti henti napas akibat sumbatan pada saat tidur, mendengkur, sindrome kegelisahan kaki, gangguan gerakan tungkai periodik menyebabkan munculnya gangguan perilaku yang menyerupai GPPH, seperti hiperaktivitas, impulsivisitas, inatensi, gangguan perilaku yang merusak. Multifaktorial artinya GPPH dan gangguan tidur diatur oleh berbagai faktor dalam neurobiologi susunan saraf pusat yang saling tumpang tindih.

Sayangnya banyak dokter yang tidak melakukan skrining rutin untuk gangguan tidur ini. Dalam satu studi yang melibatkan 830 orang tua dari anak-anak GPPH usia 2-13 tahun dilakukan survei gangguan tidur dengan menggunakan pediatric sleep questionnaire (PSQ). Hasil survei menunjukkan 86 orang tua melapor anaknya mengalami gangguan tidur, 44 orang tua mengeluhkan anaknya menderita $S D B$. Setelah dilakukan penelitian retrospektif, ternyata kurang dari $11 \%$ yang pernah mendiskusikan dengan dokternya. ${ }^{6}$ Dengan pengenalan dini, maka gangguan tidur pada anak dengan GPPH dapat diatasi, baik dengan tindakan operasi maupun dengan obat-obatan. Karena itu dalam tinjauan pustaka ini, akan diulas mengenai bagaimana proses terjadinya gangguan tidur, bagaimana kaitannya dengan GPPH, dan perlunya evaluasi lebih dalam mengenai gangguan tidur pada anak dengan GPPH dalam upaya untuk dapat memberikan penanganan GPPH yang lebih sesuai.

\section{METODE PENELITIAN}

Desain penelitian ini adalah literature review atau tinjauan pustaka. Penelusuran artikel publikasi dilakukan melalui google, google scholar, pubmed, dan research gate menggunakan kata kunci gangguan pemusatan perhatian dan hiperaktivitas (GPPH), gangguan tidur, Sleep Disorder Breathing (SDB), Restless Leg Syndrome (RLS), Periodic Limb Movement Disorder (PLMD). Kriteria pemilihan jurnal yang akan direview adalah artikel jurnal penelitian berbahasa Indonesia dan Inggris yang dapat diakses fulltext.

\section{HASIL DAN PEMBAHASAN}

\section{Gangguan Pemusatan Perhatian dan Hiperaktivitas (GPPH)}

GPPH pada tahun 1919-1920 dikenal sebagai "minimal brain damage syndrome". ${ }^{7}$ Pada tahun 1980 DSM III menyebutnya sebagai gangguan defisit atensi dengan atau tanpa hiperaktivitas. Saat ini kita menggunakan DSM-V untuk kriteria diagnostik GPPH terbaru. Berdasarkan penampilan klinisnya, GPPH terbagi dalam 3 subtipe : Predominan inatensi, predominan hiperaktivitas/impulsivitas dan kombinasi. ${ }^{1}$ Heterogenitas ini menunjukkan adanya keragaman penyebab dan faktor yang terlibat dan memediasi munculnya ekspresi gejala GPPH. Dikatakan bahwa interaksi unsur genetik dan faktor lingkungan pada awal masa perkembangan akan menciptakan kerentanan neurobiologi untuk terjadinya GPPH berupa perubahan-perubahan pada 
berbagai struktur, fungsi dan biokimia jaringan saraf mengakibatkan adanya defisit fungsi neurofisiologi. Hal tersebut didukung dan dibuktikan kemudian dengan kemajuan teknologi dalam bidang pencitraan susunan saraf pusat. Kemajuan di bidang teknologi ini, telah memberikan gambaran regio otak yang berperan dalam fungsi atensi, fungsi eksekutif, dan fungsi kontrol penghambatan sehingga menuntun kita untuk lebih dapat mengerti neurobiologi yang mendasari GPPH.

\section{Neurobiologi}

Akhir-akhir ini ditemukan bukti-bukti yang menunjukkan adanya tumpang tindih antara neurobiologi GPPH dan tidur. Karena itu sebelum kita membahas mengenai gangguan tidur pada GPPH, ada baiknya kita mengulas neurobiologi GPPH dan tidur terlebih dahulu.

\section{Neurobiologi GPPH}

Pada tahun 1996, Dahl melalui studi anatomi berhasil menemukan adanya abnormalitas pada regio otak yang mengatur fungsi kognisi, fungsi eksekutif, fungsi atensi, dan fungsi kontrol penghambatan perilaku yang konsisten ditemukan pada pasien dengan GPPH. ${ }^{8}$ Superior dan temporal cortex berkaitan dengan fungsi memfokuskan atensi, external parietal dan corpus striatal regions berkaitan dengan fungsi eksekutif motorik, hipocampus berkaitan dengan memori, prefrontal cortex berkaitan dengan pengalihan perhatian dari satu stimulus ke stimulus lainnya, dan area brainstem reticular thalamic nuclei berkaitan dengan fungsi mempertahankan atensi. $^{7}$

Hal tersebut didukung dan dibuktikan kemudian dengan kemajuan teknologi dalam bidang pencitraan susunan saraf pusat. Duston (2003) dan Rubia (2011) menggunakan MRI fungsional (fMRI) mendemonstrasikan hasil serupa berupa adanya aktivasi abnormal di area-area otak meliputi korteks prefrontal, girus cingulate anterior, dan thalamus. ${ }^{9}$ Penelitian makroanatomi yang dilakukan oleh Curatolo, Makris dan Tripp (2009) menunjukkan adanya pengecilan dari total volume otak, penurunan ukuran dari lobus frontal kanan, corpus kalosum, striatum dan serebelum pada anak dengan GPPH. ${ }^{10}$ Menurut Curatolo dan kawan-kawan (2009) dan Konrad\&Eickhoff (2010), abnormalitas pada serebrum dan serebelum ditemukan menetap pada usia lebih besar sedangkan abnormalitas pada kaudatus menjadi normal dengan perkembangan usia. ${ }^{10,11}$

Banyak studi keluarga dan studi anak kembar yang menunjukkan bahwa keluarga dari pasien GPPH mempunyai risiko yang lebih tinggi untuk menderita GPPH, dikatakan heritabilitasnya berkisar 60-90\% atau 2-8 kali dibanding populasi umum. ${ }^{12,13}$ Dari studi adopsi didapatkan bahwa anggota keluarga yang mepunyai hubungan biologis mempunyai persentase terkena GPPH yang lebih tinggi dari pada yang diadopsi. Beberapa gen yang diduga terlibat dalam proses terjadinya GPPH berkaitan dengan regulasi neurotrasmiter, antara lain DA receptor D4 (DRD4), DA receptor D5 (DRD5), DA transporter (SLC6A3/DAT1), serotonin receptor 1B (HTR1B), serotonin transporter (SLC6A4/5HTT), and protein 25 yang berhubungan dengan synaptosomal (SNAP-25) gens. Sedangkan studi pemindaian genom tentang alel yang berpotensi ADHD antara lain $5 \mathrm{p} 13,6 \mathrm{q} 12,16 \mathrm{p} 13,17 \mathrm{p} 11$ dan $11 \mathrm{q} 22-25 .^{13-15}$

Faktor lingkungan pre-, peri-, dan postnatal memegang peranan penting dalam neurobiologi GPPH. Yang dimaksud dengan faktor prenatal adalah faktor-faktor yang berhubungan dengan gaya hidup ibu selama masa kehamilan. Contohnya : paparan alkohol saat prenatal dapat menyebabkan anomali struktur otak, khususnya serebelum. ${ }^{16}$ Anak yang saat prenatal terpapar alkohol dapat menjadi hiperaktif, disruptive, impulsif dan berisiko lebih besar menderita 
gangguan psikiatri. ${ }^{17}$ Pada ibu yang merokok, risiko anak untuk menderita GPPH meningkat 2.7 kali lipat. ${ }^{18}$ Hubungan antara ibu merokok selama kehamilan dan hiperaktivitas dilaporkan sebagai hubungan dosis-respon. ${ }^{19}$ Hal ini dikarenakan efek terhadap reseptor nikotin yang mengatur aktivitas dopamin. Dopamin diyakini terlibat dalam neurobiologi GPPH. ${ }^{20}$ Faktorfaktor perinatal juga berkaitan dengan GPPH. Anak dengan berat badan lahir rendah (BBLR), risiko menderita GPPH meningkat 2 kali lipat. Komplikasi kehamilan dan persalinan juga meningkatkan risiko terjadinya GPPH. ${ }^{21}$ Faktor-faktor postnatal yang berperan dalam terjadinya GPPH antara lain malnutrisi, defisiensi zat gizi seperti defisiensi zat besi dan ketidakseimbangan antara omega 3 dan omega $6 .^{22,23}$

Dari perspektif biokimia, banyak penelitian dan studi mengemukakan terjadinya GPPH berhubungan dengan gangguan regulasi dari katekolamin, khususnya dopamin dan norepinefrin. ${ }^{10,24}$ Peranan dari berbagai neurotransmiter dalam mekanisme terjadinya GPPH ini belum dapat dipahami dan dijelaskan sepenuhnya. akan tetapi ada beberapa alasan yang dapat menjelaskan hubungan ini, antara lain regio otak yang mengalami abnormalitas pada pasien GPPH adalah regio-regio yang kaya akan signal dopamin, kemudian gen-gen yang berhubungan dengan GPPH adalah gen yang terlibat dalam regulasi dopamin ekstraseluler. ${ }^{25}$ Begitu juga dengan mekanisme kerja obat-obatan stimulan yang digunakan dalam terapi GPPH berkaitan dengan dopamin dan katekolamin lainnya. Sebagai contohnya, metilfenidat memberikan efek terapi pada GPPH dengan meningkatkan ketersediaan dopamin ekstraseluler melalui penghambatan proses pengambilan kembali dopamin ke dalam sel oleh transporter yang dibuktikan dalam studi pencitraan dengan PET. ${ }^{26}$ Amfetamin mempunyai cara kerja yang sama dengan metilfenidat, tapi amfetamin juga mempunyai efek meningkatkan pelepasan dopamin dan norepinefrin serta menurunkan aktivitas katabolisme dari katekolamin tersebut oleh enzim monoamin oksidase. ${ }^{27}$ Norepinefrin banyak ditemukan di lokasi persarafan lokus serolus, bagian dari sistem aktivasi retikular, yang merupakan pusat pengaturan atensi dan kewaspadaan. ${ }^{28}$ Selain obat-obat stimulan, Obat-obat non stimulan seperti atomoxetin dan agonis alfa juga secara efektif meningkatkan norepinefrin ekstraseluler. Dengan kata lain, obat-obat tersebut dapat memperbaiki GPPH karena mengkoreksi kekurangan dopamin yang dianggap menjadi salah satu penyebab yang mendasari GPPH.

\section{Neurobiologi Tidur}

Tidur mempunyai 2 tahapan yang berbeda, rapid eye movement (REM) dan non rapid eye movement (non REM). Tidur non REM adalah suatu periode tidur dengan aktivitas otak yang relatif rendah tapi kemampuan pengaturan otak tetap dipertahankan dan pergerakan tubuh tetap ada. Berdasarkan kedalaman tidur, tidur non REM dapat dibagi dalam 3 tahapan, di mana tahap 3 merupakan tahap tidur yang terdalam. Sedangkan menurut Mindell (2010), tidur REM adalah periode tidur dengan diikuti kondisi-kondisi seperti aktivitas korteks mengalami ketidaksinkronan, tingkat metabolisme meningkat, menurunnya tonus otot, dan episode pergerakan mata yang cepat. ${ }^{29}$

Keadaan bangun adalah hal yang berlawanan dengan tidur dalam siklus tidur-bangun. Peralihan tidur-bangun dan bangun-tidur pada setiap perubahan harian ini memerlukan interaksi yang baik dari berbagai sistem persarafan yang memang berperan dalam pengaturan keadaan bangun.

Menurut Owens, ada sebuah model yang terdiri dari 2 proses yang diduga dapat menjelaskan interaksi biologi dalam mekanisme tidur.

1. Proses homeostatik yang merupakan proses pengaturan lama dan dalamnya tidur seseorang pada satu saat yang ditentukan berdasarkan kualitas dan kuantitas tidur sebelumnya dari orang 
tersebut. Jadi dorongan tidur akan menigkat bila waktu tidur sebelumnya kurang atau kualitas tidur sebelumnya buruk.

2. Proses irama sirkardian tubuh yang merupakan proses yang mendeteksi paparan cahaya dan mensinkronisasi dengan hitungan 24 jam dalam sehari, sehingga periode waktu bangun dan tidur seseorang dapat diprediksi. Hal ini dapat terjadi karena nukleus suprakiasmatikum dari hipotalamus berespon terhadap petunjuk dari lingkungan mengenai terang dan gelap, yang kemudian mempengaruhi produksi melatonin. ${ }^{28}$ Dikatakan bahwa, produksi melatonin akan meningkat saat menjelang malam dan memfasilitasi mulainya proses tidur. Akan tetapi, selain faktor lingkungan, ternyata faktor genetik juga memegang peranan dalam menentukan jam sirkardian ini. Ada individu yang tampaknya mempunyai genetik dengan kecenderungan siklus tidur-bangunnya terseting lebih awal dan ada juga yang terseting lebih lambat. Interaksi ke 2 proses inilah yang menentukan hasil akhir lama dan dalamnya tidur seseorang.

Menurut Fuller dan kawan-kawan (2006), ada 2 jalur yang mengatur sistem bangun di otak, rute dorsal yang naik melewati talamus dan rute ventral yang naik melewati hipotalamus dan basal forebrain. ${ }^{30}$ Sedangkan untuk sistem tidur diatur oleh ventrolateral preoptic nucleus (VLPO) yang bekerja setelah mendapat input data dari proses homeostatik dan irama sirkardian. Untuk berjalannya sistem-sistem ini dibutuhkan peran dari berbagai neurotransmiter. Espana(2004) dan Lu (2010) mengatakan saraf kolinergik di talamus, hipotalamus, dan bagian dorsal midbrain mengaktifkan sinyal thalamokortikal untuk menghasilkan irama kortikal yang cepat pada keadaan bangun dan tidur REM, dan menjadi tidak aktif saat tidur non REM. ${ }^{31,32}$ Saraf-saraf di lokus ceruleus yang merupakan penghasil utama norepinefrin menjadi aktif saat bangun, kurang aktif saat tidur non REM, dan hampir tidak aktif saat tidur REM. Hal yang sama terjadi pada saraf-saraf histamin di nukleus tuberomamilari dan saraf-saraf serotonin di dorsal raphe nucleus. Sedangkan saraf orexin/hypocretin kerjanya dihambat oleh amin saat individu tersebut bangun pada siang hari, karena itu kadarnya baru mencapai puncak saat menjelang malam. Saraf-saraf orexin/hypocretin ini dibutuhkan untuk melawan dorongan rasa kantuk yang meningkat menjelang malam. Sebenarnya dopamin juga diduga memiliki kemampuan meningkatkan keterjagaan karena didapatkan adanya peningkatan kadar dopamin dan reseptor dopamin agonis saat bangun dan menurun saat tidur REM dan non REM. Selain itu, pasien-pasien yang mendapat dopamin antagonis seperti antipsikotik cenderung mengantuk. Sayangnya peranan dopamin ini belum jelas karena tidak tampak perbedaan yang nyata dalam pelepasan dopamin pada siklus tidur-bangun. ${ }^{31,32}$

Dari ke 2 neurobiologi yang sudah dibahas di atas, kita menemukan beberapa hal yang tumpang tindih seperti sistem aktivasi retikular dan korteks prefrontal bertanggung jawab pada GPPH maupun gangguan tidur, yaitu dalam hal pengaturan atensi, kewaspadaan dan tidur. Selain itu talamus di satu pihak berperan dalam memori jangka pendek dan gangguan inhibisi perilaku pada GPPH sedangkan di pihak lain juga mempunyai peran dalam regulasi tidur non REM. Berkurangnya dopamin dan norepinefrin juga ditemukan pada GPPH maupun pada gangguan tidur.

\section{Gangguan Tidur pada GPPH}

Tidur merupakan proses yang dibutuhkan otak untuk dapat berfungsi dengan baik. Tidur yang tidak cukup pada anak-anak dapat mempengaruhi cara mereka berpikir, berfungsi dan berperilaku secara negatif, bahkan dapat menunjukkan gejala hiperaktivitas, impulsivitas dan perilaku yang mirip seperti anak dengan GPPH. 
Sebaliknya anak dengan GPPH sering mengalami masalah tidur berupa sleep disorder breathing $(S D B)$, restless leg syndrome (RLS), dan periodic limb movement disorder (PLMD). Berikut kita hanya akan membahas 2 gangguan tidur yang paling sering ditemukan pada anak GPPH.

\section{Sleep Disorder Breathing (SDB)}

Sleep Disorder Breathing (SDB) adalah gangguan tidur yang mempunyai gambaran mulai dari yang paling ringan berupa mengorok sampai yang paling berat berupa Obstructive Sleep Apnoe (OSA). Gejala $O S A$ bisa berupa mengorok, berkeringat malam, tidur dengan posisi aneh, bantal yang lembap dan basah akibat berliur banyak saat tidur, tidur tidak lelap sehingga terbangun dengan rasa tidak puas, susah bangun pada pagi hari, sakit kepala saat bangun di pagi hari, mulut terasa kering, mengantuk pada siang hari, berbicara dengan suara hidung, bernafas dengan mulut, wajah adenoid, dan yang paling khas juga paling berat yaitu adanya henti nafas (apnoe) yang disertai dengan hypoxemia atau desaturasi oksigen yang mengakibatkan adanya hipoksia jaringan otak dan terganggunya tidur. ${ }^{29}$

Berdasarkan DSM V, kriteria diagnosa untuk $O S A$ adalah bila memenuhi satu dari dua kriteria yang ada :

1. Dengan polisomnografi didapatkan bukti adanya obstructive apnoe atau hypopnea saat tidur minimal 5 kali per jamnya dan mempunyai salah satu gejala berikut:

a. Masalah pernafasan pada malam hari : mengorok, gasping, breathing pause saat tidur

b. Mengantuk di siang hari, lelah, tidur yang tidak menyegarkan walaupun waktu tidur cukup, yang mana gejala ini tidak dapat dijelaskan oleh gangguan mental dan gangguan medis lainnya

2. Dengan polisomnografi didapatkan bukti adanya obstructive apnoe atau hypopnea saat tidur minimal 15 kali per jamnya dan tanpa adanya gejala penyerta ${ }^{1}$

SDB mengakibatkan defisit neurobehavioral dan neurocognitive secara konsisten. Karena itu SDB yang kronis akan mengakibatkan anak mempunyai gejala-gejala yang menyerupai GPPH. Studi Chervin (2005) menunjukkan anak-anak usia 2-13 tahun yang mempunyai kebiasaan mengorok, diperkirakan menjadi hiperaktif dalam 4 tahun ke depan. ${ }^{33}$ Pada studi yang dilakukan Dillon dan kawan-kawan (2007), menemukan anak-anak usia 5-12 tahun yang dijadwalkan untuk menjalani operasi adenotonsilektomi ternyata hampir 37\% menunjukkan gangguan perilaku merusak dan bukti-bukti yang mengarah pada GPPH, dan kira-kira $28 \%$ menderita GPPH. Hal ini dapat dijelaskan sebagai berikut : SDB mengakibatkan tidur menjadi tidak nyenyak dan terputus-putus sehingga anak mengantuk pada siang hari dan mengganggu fungsi atensi. Selain itu adanya hypopnea atau apnea akibat SDB yang terus menerus akan mengakibatkan hipoksia otak sehingga timbul sekuele neurobehavioral di prefrontal cortex. ${ }^{34}$

Akhir-akhir ini beberapa studi mendokumentasikan adanya peningkatan gejala SDB yang signifikan dari laporan orang tua pada anak-anak dengan GPPH. Diperkirakan sekitar 25\% anak dengan GPPH mempunyai hubungan dengan gejala SDB seperti mengorok. Kebiasaan mengorok dilaporkan 3 kali lebih banyak pada anak dengan $\operatorname{GPPH}(33 \%)$ dari pada anak dengan gangguan psikiatri lainnya(11\%) atau populasi anak pada umumnya (9\%). ${ }^{6}$ Akan tetapi tidak semua studi menemukan hubungan antara SDB dengan GPPH. Pada studi menggunakan polisomnogram untuk mendeteksi OSA seperti yang dilakukan O'Brien, didapatkan 26\% dari anak dengan GPPH ringan menderita OSA dan hanya 5\% dari anak dengan GPPH berat atau tanpa GPPH yang menderita OSA. ${ }^{35}$ 
Seperti yang telah disebutkan di atas, ada tumpang tindih pada area otak dalam hal pengaturan tidur, keterjagaan dan atensi sehingga memungkinkan untuk terjadinya gangguan fungsi susunan saraf pusat saat tidur kita terganggu. Bahkan bila gangguan itu terjadi pada masa perkembangan anak, diduga akan mempengaruhi perubahan struktur neuroanatomi dan fungsi dari prefrontal korteks yang bersifat menetap.

\section{Restless Legs Syndrome (RLS) and Periodic Limb Movement Disorder (PLMD)}

$R L S$ adalah gangguan neurologis yang ditandai dengan dorongan yang disadari untuk menggerakkan kaki, tanpa dapat ditahan, untuk menghilangkan rasa tidak nyaman saat pasien sedang beristirahat. Sedangkan PLMD adalah gangguan yang ditandai dengan pergerakan tungkai bawah selama 0.5-5 detik, dan berulang secara periodik setiap 15-40 detik sekali, tidak disadari, muncul saat pasien sedang tidur non REM. Dikatakan $80 \%$ pasien yang menderita $R L S$ juga menderita $P M L D$ tapi tidak sebaliknya.

Menurut DSM V kriteria diagnosa RLS adalah :

A. Sebuah dorongan untuk menggerakkan kaki, biasanya disertai atau sebagai respons terhadap rasa tidak nyaman pada kaki, ditandai hal sebagai berikut :

1. Dorongan untuk menggerakkan kaki mulai muncul atau bertambah parah saat istirahat

2. Dorongan untuk menggerakkan kaki terpuaskan sebagian atau total dengan gerakan

3. Dorongan untuk menggerakkan kaki dirasakan lebih berat pada malam hari dari pada siang hari atau hanya terjadi pada malam hari

B. Gejala pada kriteria A muncul minimal 3 kali dalam seminggu dan menetap minimal 3 bulan

C. Gejala pada kriteria A disertai distress atau hendaya yang signifikan dalam kehidupan sosial, pekerjaan, pendidikan, akademik, perilaku, atau fungsi-fungsi lain yang penting

D. Gejala pada kriteria A bukan merupakan bagian dari gangguan mental dan kondisi medis lainnya (seperti : artritis, oedema tungkai, iskemik perifer, kram tungkai) dan tidak dijelaskan lebih baik oleh kondisi tingkah laku (seperti : ketidaknyamanan akibat posisi, kebiasaan mengetuk-ngetukkan kaki)

E. Gejala-gejala tersebut bukan merupakan efek fisiologis dari obat-obatan (misalnya akatisia) ${ }^{1}$

Diagnosa PLMD baru dapat ditegakkan bila dengan polisomnogram ditemukan adanya pergerakan yang sesuai dengan kriteria $P L M D$ minimal 5 kali dalam satu periode tidur, ini jumlah yang dianggap cukup mengganggu tidur dan mempengaruhi fungsi seseorang pada keesokan harinya. Kriteria lain yang perlu diperhatikan yaitu tidak ada gangguan tidur primer lainnya. $R L S$ dan $P L M D$ mengganggu kuantitas dan kualitas tidur seseorang dengan cara yang berbeda. $R L S$ memperlambat onset tidur dan mengganggu usaha untuk tidur kembali saat terbangun di tengah malam, sedangkan PLMD menyebabkan orang yang sedang tidur menjadi terjaga dan tidur menjadi terputus-putus.

$R L S$ merupakan gangguan tidur yang cukup sering ditemukan pada pasien GPPH, prevalensinya hampir mencapai $44 \%$ dan hampir $26 \%$ pasien yang menderita $R L S$ juga menderita GPPH atau mempunyai gejala GPPH. ${ }^{36}$ Sebuah metaanalisis dari studi polisomnographic juga memverifikasi bahwa PLMD lebih banyak ditemukan pada anak GPPH dari pada anak tanpa GPPH. Hal ini menunjukkan adanya hubungan antara RLS/PLMD dan GPPH. Menurut Krause (2008), hasil Positron Emission Tomography (PET) menunjukkan bahwa penyebab yang mendasari terjadinya $R L S$ dan $P L M D$ sama dengan yang ditemukan pada GPPH yaitu adanya defisit dopamin di sistem dopaminergik susunan saraf pusat walaupun distribusi ke 2 nya berbeda. $^{37}$ Picchietti (2008) dan Coghill (2009) dalam studi genetik menunjukkan adanya perubahan pada gen dopamin transporter dan reseptor pada pasien $R L S / P L M D$ dan GPPH. ${ }^{38,39}$ 
Selain itu Schormair B (2008) dan Elia J (2010) menambahkan adanya unsur genetik lain yang tampaknya berkaitan dengan RLS/PLMD dan GPPH yaitu gen Protein Tyrosine Phosphatase Receptor type Delta (PTPRD) dan gen Nitric Oxide Synthase (NOS1).40,41 Dan yang terakhir beberapa studi secara independen menunjukkan adanya defisiensi besi yang ditandai dengan kadar serum feritin kurang dari $50 \mathrm{ng} / \mathrm{ml}$ pada ke 2 kelainan ini, yang mana zat besi dipostulasikan sebagai perantara dalam interaksi gejala antara $R L S / P L M D$ dan GPPH. ${ }^{42}$

Walaupun sejumlah besar penelitian sudah dilakukan dan menemukan bukti-bukti yang berkaitan dan sekiranya dapat menjelaskan hubungan sebab akibat antara GPPH dan gangguan tidur yang ada tapi penjelasan sepenuhnya masih merupakan misteri yang belum terpecahkan.

\section{Penatalaksanaan}

\section{OSA dan GPPH}

Dikatakan OSA pada anak-anak secara mekanis penyebabnya berbeda dengan dewasa, dengan demikian penanganannyapun jadi berbeda. Pada anak-anak, OSA biasanya disebabkan oleh pembesaran adenoid dan tonsil pars palatum yang melewati ukuran normal rongga nafas sehingga mengakibatkan sumbatan jalan nafas. OSA terjadi saat tidur karena adanya penurunan tonus otot yang memperberat sumbatan. Faktor-faktor lain yang dapat memperberat sumbatan nafas antara lain kongestif nasal yang kronis, tonus otot yang turun akibat kondisi medis lain, fitur dari orofaring itu sendiri, dan obesitas. Karena itu penanganan yang cocok adalah operasi adenotonsilektomi. ${ }^{43,44}$ Didapatkan bahwa 50\% dari anak yang tadinya memenuhi kriteria GPPH sebelum operasi, tidak lagi memenuhi kriteria tersebut setelah menjalani operasi adenotonsilektomi. ${ }^{45}$ Untuk hasil adenotonsilektomi yang kurang memuaskan, nasal continous positive airway pressure mungkin lebih efektif. Dan untuk kasus-kasus yang berat, dapat dilakukan trakeostomi.

\section{RLS/PLMD dan GPPH}

Terapi yang direkomendasikan pada $R L S / P L M D$ adalah

- Menjaga higiene tidur

- Konsumsi suplemen besi untuk anak-anak dengan kadar feritin $\leq 50 \mathrm{ng} / \mathrm{mL}$

- Hindari penggunaan obat-obatan seperti antihistamin, preparat obat flu, SSRI dan obat anti muntah yang dapat memperberat $R L S / P M D$

- Obat-obat dopamin agonis

Obat-obat dopamin agonis adalah obat-obat yang meningkatkan kadar dopamin. Pemberian obat dopamin saat tidur dapat mengurangi gejala $R L S$ dan PLMD. Ropinirole, pramipexole, dan rotigotine adalah obat-obat dopmain agonis yang telah disetujui FDA untuk mengobati $R L S$ derajat sedang sampai berat. ${ }^{46}$ Walaupun demikian obat-obat ini mempunyai efek samping mual, pusing, dan beberapa efek samping lainnya. Levodopa dan carbidopa memberikan hasil terapi jangka pendek yang baik. Meskipun obat dopamin agonis efektif untuk $R L S$ tapi pemakaian jangka panjang dapat menyebabkan perburukan gejala yang disebut augmentation. Pemakaian kronis obat dopamin agonis menyebabkan gejala $R L S$ lebih cepat muncul pada malam hari, kemudian gejala mulai muncul juga di siang hari dan lama-lama gejala muncul hampir di sepanjang hari. Untungnya efek samping ini berisfat reversibel.

- Obat-obat lain seperti :

$>$ Benzodiazepin dapat membantu mengurangi gejala RLS yang ringan atau intermiten. Efek sampingnya : mengantuk, dapat mengakibatkan sleep apnea. Contoh : clonazepam dan diazepam 
$>$ Opioid seperti kodein, propoxyphene, or oxycodone dapat membantu mengurangi rasa sakit dan membantu relax pada gejala yang berat.

Anticonvulsant seperti gabapentin dan pregabalin dapat mengurangi rasa sakit dan tidak nyaman seperti sensasi ada yang merayap di kaki. Gabapentin disetujui FDA untuk terapi $R L S$ sedang-berat. Efek samping : pusing, lelah, mengantuk

\section{KESIMPULAN DAN SARAN}

Menurut literatur, 25-50\% orang tua melaporkan anak dengan GPPH memiliki gangguan tidur. Prevalensi gangguan tidur pada GPPH ini kira-kira 5 kali lebih banyak dari pada tanpa GPPH. RLS/PLMD dan SBD merupakan gangguan tidur yang cukup sering ditemukan pada pasien GPPH, prevalensinya mencapai $44 \%$ dan $25 \%$. Sayangnya banyak dokter yang tidak melakukan skrining rutin untuk gangguan tidur ini. Padahal dengan pengenalan dini, maka gangguan tidur pada anak dengan GPPH dapat diatasi, baik dengan tindakan operasi maupun dengan obatobatan, sehingga diharapakan ada perbaikan dari gejala GPPH.

\section{Ucapan Terima Kasih}

Penulis berterima kasih dan menyampaikan penghargaan yang mendalam kepada mereka yang berpartisipasi dalam karya tulis kami. Penulis ingin mengucapkan terima kasih kepada keluarga yang mendukung kami.

\section{REFERENSI}

${ }^{1}$ American Psychiatric association. Diagnostic and statistical manual of mental disorders. 5th (DSM-V). 5th ed. Arlington, VA, American Psychiatric Association; 2013.

${ }^{2}$ Rowland AS, Lesesne CA, Abramowitz AJ. The epidemiology of attention-deficit/hyperactivity disorder (ADHD): a public health view. Ment Retard Dev Disabil Res Rev. 2002;8 (3):162-170.

${ }^{3}$ Bartholomew, K., \& Owens, J, M.D., MPH. Sleep and AD/HD: A review. Med Health R I. 2006;89:91-3.

${ }^{4}$ Spruyt K, Gozal D. Sleep disturbances in children with attention-deficit/hyperactivity disorder. Expert Rev Neurother. 2011 Apr;11(4):565-77.

${ }^{5}$ Weiss DMD, Salpekar J. Sleep Problems in the Child with Attention-Deficit Hyperactivity Disorder. CNS Drugs. 2012 Sep 14;24(10):811-28.

${ }^{6}$ Chervin, R. D., Archbold, K. H., Panahi, P, Pituch, K. J. Sleep Problems Seldom Addressed at Two General Pediatric Clinics. Pediatrics. 2001;107 (6):1375-1380.

${ }^{7}$ Sadock BJ, Sadock VA, Ruiz P, Kaplan HI. Kaplan \& Sadock's comprehensive textbook of psychiatry. Philadelphia: Wolters Kluwer Health/Lippincott Williams \& Wilkins; 2009.

${ }^{8}$ Dahl RE. The regulation of sleep and arousal: Development and psychopathology. Dev Psychopathol. 1996 Dec;8(01):3-27.

${ }^{9}$ Durston, S., Tottenham, N.T., Thomas, K.M., Davidson, M.C., Eigsti, I.M., Yang, Y., Ulug, A.M., \& Casey, B.J. Differential patterns of striatal activation in young children with and without ADHD. Soc Biol Psychiatry. 2003;53:871-8.

${ }^{10}$ Curatolo P, Paloscia C, D'Agati E, Moavero R, Pasini A. The neurobiology of attention deficit/hyperactivity disorder. Eur J Paediatr Neurol. 13(4):299-304.

${ }^{11}$ Konrad K, Eickhoff SB. Is the ADHD brain wired differently? A review on structural and functional connectivity in attention deficit hyperactivity disorder. Hum Brain Mapp. 2010 Jun 1;31(6):904-16.

${ }^{12}$ Sharp SI, McQuillin A, Gurling HM. Genetics of attention-deficit hyperactivity disorder (ADHD). Neuropharmacology. 2009;57:590-600. 
${ }^{13}$ Gizer IR, Ficks C, Waldman ID. Candidate gene studies of ADHD: a metaanalytic review. Hum Genet. 2009; 126:51-90.

${ }^{14}$ Smoller JW, Biederman J, Arbeitman L, Doyle AE, Fagerness J, Perlis RH, Sklar P, Faraone SV. Association between the 5HT1B receptor gene (HTR1B) and the inattentive subtype of ADHD. Biol Psychiatry. 2006;59:460-7.

${ }^{15}$ Mick E, Faraone SV. Genetics of attention deficit hyperactivity disorder. Child Adolesc Psychiatr Clin N Am. 2008;17:261-84.

${ }^{16}$ Coffin JM, Baroody S, Schneider K, O’Neill J. Impaired cerebellar learning in children with prenatal alcohol exposure: a comparative study of eyeblink conditioning in children with ADHD and dyslexia. Cortex. 2005;41:389-98.

${ }^{17}$ D'Onofrio BM, Van Hulle CA, Waldman ID, Rodgers JL, Rathouz PJ, Lahey BB: Causal inferences regarding prenatal alcohol exposure and childhood externalizing problems. Arch Gen Psychiatry. 2007;64:1296-304.

${ }^{18}$ Milberger S, Biederman J, Faraone SV, Chen L, Jones J: Is maternal smoking during pregnancy a risk factor for attention deficit hyperactivity disorder in children? Am $\mathbf{J}$ Psychiatry. 1996;153:1138-42.

${ }^{19}$ Kotimaa AJ, Moilanen I, Taanila A, Ebeling H, Smalley SL, McGough JJ, Hartikainen AL, Jarvelin MR: Maternal smoking and hyperactivity in 8- year-old children. J Am Acad Child Adolesc Psychiatry. 2003;42:826-833.

${ }^{20}$ Weiss S, Tzavara ET, Davis RJ, Nomikos GG, Michael McIntosh J, Giros B, Martres MP: Functional alterations of nicotinic neurotransmission in dopamine transporter knock-out mice. Neuropharmacology. 2007;52:1496-508.

${ }^{21}$ Taylor E, Rogers JW: Practitioner review: early adversity and developmental disorders. J Child Psychol Psychiatry. 2005;46:451-67.

${ }^{22}$ Raz R, Gabis L: Essential fatty acids and attention-deficit-hyperactivity disorder: a systematic review. Dev Med Child Neurol. 2009;51:580-92.

${ }^{23}$ Juneja M, Jain R, Singh V, Mallika V: Iron Deficiency in Indian Children with Attention Deficit Hyperactivity Disorder. Indian Pediatr. 2010;955-8.

${ }^{24}$ Tripp, G., Wickens, J.R. Neurobiology of ADHD. Neuropharmacology. 2009;57:579-89.

${ }^{25}$ Swanson, J.M., Flodman, P., Kennedy, J., Spence, M.A., Moyzis, R., Schucka, S., Murias, M., Moriarity, J., Barr, C., Smith, M., Posner, M. Dopamine genes and ADHD. Neurosci Biobehav Rev. 2000;25:21-5.

${ }^{26}$ Rosa-Neto P, Lou HC, Cumming P, Pryds O, Karrebaek H, Lunding J, Gjedde A. Methylphenidate-evoked changes in striatal dopamine correlate with inattention and impulsivity in adolescents with attention deficit hyperactivity disorder. NeuroImage. 2005;25 (3):868-76.

${ }^{27}$ Del Campo N, Chamberlain SR, Sahakian BJ, Robbins TW. The Roles of Dopamine and Noradrenaline in the Pathophysiology and Treatment of Attention- Deficit/Hyperactivity Disorder. Biol Psychiatry. 2011;69 (12):e145-57.

${ }^{28}$ Owens, J.A. The ADHD and Sleep Conundrum: A Review. Dev Behav Pediatr. 2005;6 (4):312-22.

${ }^{29}$ Mindell JA, Owens JA. A Clinical Guide to Pediatric Sleep: Diagnosis and Management of Sleep Problems. Phila Lippincott Williams Wilkins. 2010;

${ }^{30}$ Fuller PM, Gooley JJ, Saper CB. Neurobiology of the sleep-wake cycle: sleep architecture, circadian regulation, and regulatory feedback. J Biol Rhythms. 2006;21 (6):482 (12).

${ }^{31}$ Espana, RA; Scammell TE. Sleep neurobiology for the clinician. Sleep. 2004;

${ }^{32}$ Lu B, Zee P. Neurobiology of Sleep. Clin Chest Med. 2010;31:309-18.

${ }^{33}$ Chervin, R. D., Ruzicka, D. L., Archbold, K. H., Dillon, J. E. Snoring Predicts Hyperactivity Four Years Later. Sleep. 28(7):885-90. 
${ }^{34}$ Hodges, E.K., Bloomfied, E., Coulas, T., Giordani, B. Cognitive and behavioral change after adenotonsillectomy in children with sleep-disordered breathing: A review. Minerva Psichiatr. 49 (4):307-20.

${ }^{35}$ O’Brien, L. M., Holbrook, C. R., Mervis, C. B., Klaus, C. J., Bruner, J. L., Raffield, T. J., Rutherford, J., Mehl, R. C., Wang, M., Tuell, A., Hume, B. C., Gozal, D. Sleep and Neurobehavioral Characteristics of 5- to 7-Year-Old Children With Parentally Reported Symptoms of Attention-Deficit/Hyperactivity Disorder. Pediatrics. 111 (3):554-63.

${ }^{36}$ Cortese S, Konofal E, Lecendreux M, et al. Restless legs syndrome and attention-deficit/ hyperactivity disorder: a review of the literature. Sleep. 2005;28 (8):1007-1013.

${ }^{37}$ Krause J. SPECT and PET of the dopamine transporter in attention-deficit/hyperactivity disorder. Expert Rev Neurother. 2008;8:611-25.

${ }^{38}$ Picchietti, M. A., Picchietti, D. L. Restless Legs Syndrome and Periodic Limb Movement Disorder in Children and Adolescents. Semin Pediatr Neurol. 2008;15:91-9.

${ }^{39}$ Coghill D, Banaschewski T. The genetics of attention-deficit/hyperactivity disorder. Exper Rev Neurother. 2009;9:1547-65.

${ }^{40}$ Schormair B, Kemlink D, Roeske D, Eckstein G, Xiong L, Lichtner P, et al. PTPRD (protein tyrosine phosphatase receptor type delta) is associated with restless legs syndrome. Nat Genet. 2008;40:946-8.

${ }^{41}$ Elia J, Gai X, Xie HM, Perin JC, Geiger E, Glessner JT, et al. Rare structural variants found in attention-deficit hyperactivity disorder are preferentially associated with neurodevelopmental genes. Mol Psychiatry. 2010;15:637-46.

${ }^{42}$ Oner, P., Dirik, E.B., Taner, Y., et al. Association between low serum ferritin and restless legs syndrome in patients with attention deficit hyperactivity disorder. Tohoku J Exp Med. 2007;213:269-76.

${ }^{43}$ Galland BC, Dawes PJ, Tripp EG, Taylor BJ. Changes in behavior and attentional capacity after adenotonsillectomy. Pediatr Res. 2006;59:711-6.

${ }^{44} \mathrm{Li} \mathrm{HY}$, Huang YS, Chen NH, et al. Impact of adenotonsillectomy on behavior in children with sleep-disordered breathing. 2006;116:1142-7.

${ }^{45}$ Dillon, J.E. Blunden, S. Ruzicka, D.L. Guire, K.E. Champine, D. Weatherly, R.A. Hodges, E.K. Giordani, B.J. Chervin, R.D. DSM-IV Diagnoses and Obstructive Sleep Apnea in Children Before and 1 Year After Adenotonsillectomy. Am Acad Child Adolesc Psychiatry. 2007;46 (11):1425-36.

${ }^{46}$ England SJ, Picchietti DL, Couvadelli BV, Fisher BC, Siddiqui F, Wagner ML, et al. L-Dopa improves Restless Legs Syndrome and periodic limb movements in sleep but not Attention-Deficit-Hyperactivity Disorder in a double-blind trial in children. Sleep Med. 2011 May;12(5):471-7. 